\title{
Perverting the Course of Politics
}

\author{
ROBERT E. GOODIN*
}

Lawyers talk of the common law offence of 'perverting the course of justice' by bribing or intimidating judges or jurors, lying to the police or court, concealing or destroying or fabricating evidence. This article argues that the same things are wrong, and wrong for the same reasons, politically as judicially: they prevent people from knowing and applying for themselves the rules by which they are ruled. The sort of excuses typically offered for those perverse practices in politics - that 'it made no difference', that 'they could and should have resisted' or that it is merely a matter of 'fair adversarial competition' - would be laughed out of a court of law, and they should be shunned politically for the same reasons as judicially.

In England, there is a common law offence called 'perverting the course of justice'. ${ }^{1}$ It covers things like bribing or intimidating judges and jurors; lying to the police or to the court; concealing or destroying or fabricating evidence. Perverting the course of justice is a serious offence. Those convicted can be (albeit nowadays rarely are) imprisoned for life. ${ }^{2}$

Here, I want to consider whether there might be a parallel political offence, 'perverting the course of politics'. That is to say, might bribery or intimidation or giving false information or fabricating evidence be regarded as wrong, politically, in the same way and for much the same reason as they are, legally?

One easy - too easy - way to condemn those practices politically would be to say that they are 'undemocratic'. That is true too, of course. Bribes circumvent votes; lies preclude genuine consent; and so on. Hence, we certainly can say, with little further ado, that those sorts of practices 'pervert the course of democratic politics'.

Here, however, I shall be striving for a result that is rather more general than that. It is not just democratic politics but politics tout court (or anyway a class much broader than merely democratic politics) that is perverted by those practices. Demonstrating that is the main aim of this article.

The target of the argument is the 'resigned realist'. I discuss several more particular propositions associated with that position in the section on discredited excuses below. But for now we can just think of the kind of person who - when told about some egregious act of lying, bribery or intimidation on the part of political leaders - says, with a sigh,

* School of Philosophy, Research School of Social Sciences, Australian National University (email: goodinb@coombs.anu.edu.au). For comments on earlier drafts, I am grateful to John Deigh, Jenny Mansbridge, Larry May, Sue Mendus, Albert Weale and this Journal's referees. I should also acknowledge the more impersonal contributions of George W. Bush and Tony Blair.

${ }^{1}$ William Blackstone, 'Of Offences against Public Justice', Commentaries on the Laws of England (Oxford: Clarendon Press, 1769), vol. 4, chap. 10. In some Australian jurisdictions it is a statutory offence, and some aspects of it are covered by statutes in England as well.

2 In Britain, 'no sentence above 10 years has been passed in the last century for this offence' (Susan S. M. Edwards, 'Perjury and Perverting the Course of Justice Considered' (2007), available at $\langle$ www.buck.ac.uk/publicity/academics/articles/edwards-paptcojc.pdf〉 (accessed 29 Oct. 2007), p. 1). 
'So, what did you expect?' 'Better,' I reply, 'and we ought to expect better politically for broadly the same reasons we do legally.' We ought to reject the sort of political excuses resigned realists ordinarily give for those sorts of practices for broadly the same reasons that we rightly laugh them out of courts of law.

One might initially be sceptical of the suggestion that the same things for the same reasons pervert the course both of justice and of politics. I discuss and dismiss a few grounds for such scepticism in the next section. I then go on to show what are good grounds for the analogy in the following section and what might follow from thinking in terms of politics and its perversion in this way in the two sections after that. Having devoted the bulk of the article to meeting the 'resigned realist' on his or her own pragmatic ground, I close in the final section with reminders of what other more principled reasons we might have for abhorring these perversions of political and legal due process.

\section{RESISTING THE ANALOGY}

\section{Politics Has No Natural Course}

One obvious reason to resist any analogy between 'perverting the course of justice' and 'perverting the course of politics' is that the political process does not have a natural 'course' in the same way that the legal process does.

The 'course of justice' begins with an event that ought to lead to legal enquiries and might lead to legal proceedings. It ends when enquiries are closed or proceedings are concluded. Over the normal course, the enquiries, investigation and any ensuing proceedings would be conducted in a manner designed systematically to ascertain the true facts of the matter. The course of justice is often seen in stylized form as a serial, indeed, linear process: investigation, indictment, trial, deliberation, decision. Perverting the course of justice is a matter of derailing that systematic pursuit of the truth, at some point or another.

The 'course of politics' is decidedly messier than that. ${ }^{3}$ Certainly it is less linear. Proposals are made, dropped, resurrected, ignored, enacted, amended, repealed and even reinstated. Alternative proposals, often orthogonal to one another, vie for a place on the political agenda. Political deliberations are anything but linear, certainly within mass publics and oftentimes even in the formalized proceedings of legislative assemblies.

Nor is there any settled end point in the political process. Any decision can, in principle, be revisited and revised by some subsequent body that is just as sovereign as the previous one that made that decision. So in that sense too, the political process cannot ever be said to have 'run its course', in the same way the legal process can.

Relatedly, the administration of justice is a teleological process, aiming to establish the truth about guilt or innocence to the best of our ability, whereas politics has no such settled end point in view. The image of a process being 'on course' or 'blown off course' presupposes a destination in view. With the administration of justice, we have just such a destination. With politics, we do not.

But upon reflection, we do not need to have an end point in view, a 'right answer' to be found, in order to know that certain sorts of practices cause the political process to deviate unacceptably from its due course. Nor do we need to envisage that the process will

\footnotetext{
3 Indeed, Olsen describes it as a 'garbage can' comprised of problems looking for solutions, standing 'solutions' looking for problems to which they can be attached, and people looking for things to do (Johan P. Olsen, 'Public Policy-Making and Theories of Organizational Choice', Scandinavian Political Studies, 7 (1972), 45-62).
} 
necessarily eventually 'run its course', and issue in some final determination that is settled for all time, in order to say that certain practices interfere with the due course of politics.

Imagine a ruler who cancels elections or suspends parliament. We can say with confidence that this ruler has thereby 'perverted the course of politics' in the country. ${ }^{4}$ We do not need to know exactly how the election would have turned out, or exactly what statutes the disbanded legislature would have enacted. All we need to know is that politics - as it had been being conducted in that country, through elections and parliaments - has now been suspended.

'Perverting the course of politics' should thus be defined purely in terms of interference with processes and procedures. Outcomes may or may not have been altered. ${ }^{5}$ But even where the outcome has been altered by the intervention, that is not constitutive - it is merely a consequence - of 'perverting the course of politics'. It is the interference with the ordinary procedures of politics, rather than the altered outcome, that constitutes the defining feature of 'perverting the course of politics'.

Upon reflection, the same is true judicially. When we talk about 'perverting the course of justice', it is not so much the end point of the legal process - its teleology or finality or determinateness - that we are pointing to. When we talk about 'letting justice run its course', we do not mean 'reaching some specific substantive conclusion'. Instead, we mean merely letting the process play itself out unimpeded. The 'course of justice' is just that - a 'course', not a 'conclusion'. With the administration of justice just as with politics, it is deviation from those due processes that constitutes the perversion. ${ }^{6}$

Complaining about untoward interferences with due processes in the administration of justice or the practice of politics is not necessarily to make a fetish of procedures above all else, in either realm. Undoubtedly, we do value due legal process in its own right, as a core element of natural justice and fundamental fairness. Another important part of the reason we prefer some legal procedures to others - part of the reason we regard some as constituting 'due process' - is that we also think that, in general and on average, those procedures are more likely to lead to substantively correct outcomes than others. ${ }^{7}$

The same is true in politics. Political procedures can be valuable for their own sake, but they are also valuable as an indispensable means to other ends. Assuming that people are the best judges of their own interests, democratic procedures arguably maximize social welfare; consociational joint decision-making arguably maximizes social harmony; and so

${ }^{4}$ Suspending judges might be another example, in a country where independent judicial review is an important part of the political process; see World Bank, The State in a Changing World: World Development Report 1997 (Oxford: Oxford University Press for the World Bank, 1997), p. 100.

${ }_{5}$ Maybe the ruler would have been re-elected, after all; maybe the legislation the ruler feared, when suspending parliament, would not have been enacted.

6 'Perverting the course of justice' is defined in terms of procedural irregularities - associated with bribery, intimidation and falsehoods - rather than the substantive errors to which such intrusions lead. We can make substantive errors without the intrusion of any of the procedural irregularities that constitute 'perverting the course of justice'. Whenever a court rules wrongly, it commits an injustice, of course. But 'perverting the course of justice' would be said to have occurred only where there has been an attempt to upset our procedures for getting it right. Ruling wrongly on the basis of an accidental error, however, would hardly be said to count as a 'perversion of the course of justice'.

${ }^{7}$ Saying that procedures are valued partly (or even wholly) as the means to establishing the truth (about guilt and innocence, duty and entitlement, etc.) is not to minimize their value but rather to reiterate it. Being the best means for attaining an invaluable social end - truth about guilt and innocence, duty and entitlement - makes 'due process' more valuable, not less so. See, more generally, Thomas R. Kearns, 'On De-moralizing Due Process', in J. R. Pennock and J. W. Chapman, eds, Nomos XVIII: Due Process (New York: New York University, 1977), pp. 229-54. 
on. So in politics just as in the administration of justice, we do not have to think that procedures are ends in themselves to agree that they are important and valuable, and that perverting them is a very bad thing.

\section{Making Rules Versus Applying Them}

Another difference between 'perverting the course of justice' and 'perverting the course of politics' might be thought to be that the administration of justice involves applying rules, whereas politics involves making them. Phrased so starkly, that distinction is of course somewhat overdrawn. ${ }^{8}$ But the larger question for present purposes is what difference that distinction (even in its most exaggerated form) would actually make to the issue at hand. Suppose 'the course of justice' involved merely applying rules, while 'the course of politics' involved making them. What would follow?

Clearly, some things that count as 'perversions' of the due course of applying rules would not count as perversions in the due course of making them. For example, those charged with making rules would typically be expected to exercise 'independent judgement', and it would count as a perversion of that process for them to defer completely to someone else's judgement in the matter at hand. In contrast, it presumably would be perfectly appropriate for those charged with merely applying rules to defer to certain others, such as their superiors in the official hierarchy, and more generally to rely on precedent, customary practice and so on in applying the rules.

Thus, the processes of making versus applying rules are indeed different, and some practices that would be proper in one connection would be improper in the other. Still, is it remotely credible that the specific things embraced by the notion of 'perverting the course of justice' - bribery or intimidation or giving false information or fabricating evidence - would not count equally as perversions as regards both the making and the applying of rules? I think not. Different though the two practices are in various other respects, none of those differences would seem to make a difference in this respect.

\section{GROUNDING THE ANALOGY}

So far I have just been trading on an analogy, and defending against scepticism that it might be a bad analogy. Next, I shall provide some positive analysis as to why it is actually a good analogy. The underlying logic of what is involved in 'ruling via rules' is, I suggest, what explains why the same practices would be wrong, and wrong for the same reasons, both judicially in the application of rules and politically in the making of rules.

Ruling via rules is not the only possible way that rulers can rule, to be sure. They can rule by fiat, issuing orders one after another, each utterly unrelated to the last. Doing so would hardly count as a form of 'justice', perhaps. There is arguably something internal to the logic of the concept of 'justice' that requires it to be rule-governed. But there is nothing internal to the concept of 'politics' that would preclude fiat rule qualifying as a form of politics. Thus, my conclusions will not extend to politics tout court. Instead, they will apply merely to those forms of politics that aspire to rule via rules.

\footnotetext{
8 Rules always have 'open texture', affording a certain measure of discretionary power to those applying them to, in effect, 'make' rules for themselves; and any making of rules must be done in a rulebound way, if only in the sense that the 'rule of recognition' must recognize the rules thus made as being binding within the system of law there in force (see H. L. A. Hart, The Concept of Law, 2nd edn (Oxford: Clarendon Press, 1994), chaps 5 and 7).
} 
Still, most rulers - democratic, autocratic and everything in between - do indeed aspire to rule via rules. ${ }^{9}$ They do so for good reasons. 'Ruling via rules' involves governing people's behaviour through prescriptions that people can anticipate and apply for themselves. That is a familiar thought which occurs early in virtually every discussion of the Rule of Law. ${ }^{10}$ There are many respects in which it might be desirable for people to be able to anticipate and apply the ruler's rules for themselves. Eschewing appeals to high-minded moral principles, I shall focus instead narrowly on the efficiency gains from their so doing.

First, let us examine the situation from the point of view of the ruler. Enforcement costs are minimized, in so far as people subject to rules anticipate and apply those rules themselves. Minimizing enforcement costs in this way is of course a huge attraction for rulers, autocratic and democratic alike. That is what rulers gain by 'ruling via rules'. ${ }^{11}$

Notice secondly, however, that there is also a huge pragmatic advantage for those who are being ruled to be 'ruled via rules'. Being able to anticipate the prescriptions that will apply to them enables people to minimize the burdens of complying with those prescriptions. If they know what the prescriptions are going to require of them, and if they have alternative ways they can meet those demands, people can adapt their behaviour to a least-cost course of compliance. ${ }^{12}$

What is crucial in producing those advantages for both the ruler and the ruled is the ruled being able to anticipate - often far into the future ${ }^{13}$ - the requirements by which they will be bound. This, as Raz says, is one of the prime 'reasons for valuing the rule of law':

We value the ability to choose styles and forms of life, to fix long-term goals and effectively direct one's life towards them. One's ability to do so depends on the existence of stable, secure

9 That is the crucial respect in which there is no difference between Augustine's law-governed kingdom and a well-organized band of rulers, or between Fuller's well-run corporation and a law-governed polity (see Augustine, The City of God against the Pagans, ed. R. W. Dyson (Cambridge: Cambridge University Press, 1998), bk. IV, chap. 4, and Lon L. Fuller, The Morality of Law, revd edn (New Haven, Conn.: Yale University Press, 1969), p. 207).

${ }^{10}$ In The Road to Serfdom (Chicago: University of Chicago Press, 1944), p. 54, Friedrich Hayek writes, 'stripped of all technicalities [the rule of law] means that government in all its actions is bound by rules fixed and announced beforehand - rules which make it possible to foresee with fair certainty how the authority will use its coercive powers in given circumstances, and to plan one's individual affairs on the basis of this knowledge'. Law 'is basically a matter of providing the citizenry with a sound and stable framework for their interactions with one another', according to Fuller, Morality of Law, p. 210. 'Most law, most of the time, works through self-application by agents acting for reasons, following the reasons that the normative force of the law indicates', in the terms Waldron uses to gloss Hart and Sacks's analysis of The Legal Process (see Jeremy Waldron, 'The Concept and Rule of Law' (paper presented at the New York University School of Law, 2006); available at <www.law.nyu.edu/clppt/program2006/ readings/Concept $\% 20$ and $\% 20$ Rule $\% 20$ of $\% 20$ Law $\% 20$ WALDRON.pdf $>$, p. 25, and Henry M. Hart and Albert Sacks, The Legal Process, ed. William N. Eskridge and Philip P. Frickey (New York: Foundations Press, 1994), pp. 120-1).

${ }^{11}$ Even a wicked regime or a group of gunmen would find it convenient to rule in this way; see Matthew H. Kramer, In Defense of Legal Positivism (Oxford: Oxford University Press, 1999), p. 67.

${ }^{12}$ This is to adopt the efficiency-based argument for the rule of law developed most fully by Joseph Raz, 'The Rule of Law and Its Virtue', Law Quarterly Review, 93 (1977), 195-211. Fuller, Morality of Law, pp. 208, 210, 212, dubs that sort of analysis the 'expediency view'.

13 As Raz, 'The Rule of Law and Its Virtue', p. 199, says: 'people need to know the law not only for short-term decisions (where to park one's car, how much alcohol is allowed in duty free, etc.) but also for long-term planning. Knowledge of at least the general outlines and sometimes even of details of tax law and company law are often important for business plans which will bear fruit only years later. Stability is essential if people are to be guided by law in their long-term decisions'. 
frameworks for one's life and actions. The law can help secure such fixed points of reference ... by a policy of self-restraint designed to make law itself a stable and safe basis for individual planning. ${ }^{14}$

Crucially, for the ruled to be able to anticipate what will be required of them and to adapt their behaviour accordingly, they need to be able to anticipate two things. They need to be able to anticipate both what rule will apply to them and how it will apply to them. Both are clearly important aspects of the Rule of Law in ordinarily judicial settings. That is often remarked upon. What is much less often noticed or remarked upon is that being able to anticipate what rule will apply is an issue that arises in the making of rules as well as in the application of them. It is thus an issue that arises in politics as much as - and perhaps even more than - in the administration of justice. ${ }^{15}$

Certainly, people need to be able to anticipate which law, among the many laws already on the statute book, will apply to them in any particular instance. That is a familiar part of the familiar Rule of Law story; but that is only part of the story. For the same reason, people also need to be able to anticipate politically which law, of the many possible laws that might subsequently be enacted, will actually be enacted. In order to realize the advantages that come from being able to adapt your behaviour in anticipation of the rules that will be applied to you, you need to be able to anticipate what rules will be made as well as which rules will be applied.

When I say that 'perverting the course of politics' is wrong for the same reasons 'perverting the course of justice' is wrong, the reason in both cases is that the perversions in view interfere with 'rule via rules' and people's being able to anticipate and apply the prescriptions that will govern their lives. The social importance of anticipatable rules - being able to anticipate what rules will apply and how they will apply - is, I suggest, what connects the two cases.

As I said, there are forms of political rule that do not involve 'ruling via rules'. Precisely because such forms of rule make no attempt at ruling in ways that those subject to them can anticipate in advance, they cannot be said to be 'perverted' by practices (like bribery, lying and so on) that stand in the way of 'ruling via rules'. So, to repeat my assumptions above, my conclusions cannot genuinely be said to apply to all forms of politics as such: merely to forms of politics that attempt to 'rule via rules'. Still, I reiterate, that is a much broader category of political rule than democratic rule alone.

\section{PERVERSIONS RENDERING RULE UNANTICIPATABLE}

'Perverting the course of politics', as I have been discussing it, involves a variety of practices: bribery, intimidation, giving false information or fabricating evidence. Let us now see how such practices interfere with 'ruling via rules'.

Forms of political rule that are designed to rule via rules, broadly stable in form, amount to reason-giving systems. That is precisely what is blocked by 'perversions' of

${ }^{14}$ Raz, 'The Rule of Law and Its Virtue', p. 203.

15 Obvious though it is to extend in this way familiar Rule of Law principles to the making of law, it has not been much done in these discussions. Friedrich Hayek, The Constitution of Liberty (Chicago: University of Chicago Press, 1960), p. 221, following Smith, supposed that no interference in violation of the rule of law would be involved in 'the passing of a new rule by the legislature so long as it was intended to apply equally to all people for an indefinite period of time'. Raz, 'The Rule of Law and Its Virtue', p. 200, remarks similarly on 'particular laws' being perfectly consistent with the rule of law, so long as they arise under 'general' ones. 
bribery or intimidation or giving false information or fabricating evidence. All of those in one way or another falsify the reasons you have and give for your actions, politically just as judicially. And if subjects do not know why rulers have done what they have done, they cannot anticipate with any confidence what the rulers might do next.

Where a ruler has been bribed, any ruling that arises as a result of the bribe does not form part of any principled pattern. Nothing about the content of the ruling gives us any clues as to how the ruler might rule in future on similar cases. It all depends on the size of the bribes on offer for doing one thing rather than another. Of course, 'selling oneself to the highest bidder' is itself a pattern, but falling into that pattern does little to enable the subjects to anticipate what the rulings will be. Even in a world of transparent bribery, exactly who will be willing and able to offer the most tempting bribe might be hard to predict in advance.

Intimidation produces a similar case. When rulers are intimidated into doing something they would not otherwise have done, then their past behaviour is not a good guide to their future rulings. They will rule similarly in the future only if similarly intimidated in the future.

Once again, the pattern of power relations is sometimes such that ongoing intimidation is perfectly predictable. But even so, to anticipate what an intimidated ruler is likely to demand of us, we need to anticipate not only that intimidation will occur but also in what direction. We need to be able to predict what the intimidators will demand of our rulers, in order to know what will be demanded of us.

Lies work similarly. When lying, rulers give false reasons for what they have done. When subjects lie successfully to a ruler (that is, in ways that succeed in causing things to be done that would not otherwise have been done), the ruler acts on reasons thought to be true that are actually false. Subjects trying to anticipate the ruler's subsequent behaviour on the basis of the ruler's previous behaviour would be frustrated in both cases. That is obviously so in the case of the lying ruler. It is equally true in the case of the deceived ruler: to know what the ruler is likely to prescribe in the future, they would need to know what lies the ruler will be told.

All three practices - corruption, intimidation, lying - make the behaviour of rulers largely inscrutable, or anyway very much harder to predict. In that way, all interfere with 'ruling via rules'. That is why all three count as 'perverting the course of politics', or at least that sort of politics that does indeed aspire to 'rule via rules'.

\section{EXCUSES DISCREDITED}

Comparing 'perverting the course of politics' to 'perverting the course of justice' enables us to see just how feeble are many standard excuses offered by the 'resigned realist' for lying, bribery and intimidation in politics. Here, I shall consider three, commonly heard in political connections, but clearly untenable in the legal context. Reflecting upon the reasons we have no truck with them legally, we can see why we ought to have no truck with them politically, either.

\section{It Made No Difference}

One of the most common excuses for misbehaviour in politics is that 'Everyone is doing it' or 'If I hadn't, someone else would have ...' (fill in the blank as you will - would have bribed the public official, put out misleading information, brought illicit pressure to bear).

At root, this group of excuses amounts to a claim that it 'made no difference' whether you did it or not. Superfluous interventions (where the outcome was over-determined) or 
unsuccessful interventions (ones that fail to alter the outcome) both 'make no difference'. Hence, on this argument, they ought not to be blame-worthy. Support for this proposition can be found in the very phrasing of the offence, 'perverting' the course of justice or of politics. As defined by the Oxford English Dictionary, to 'pervert' is 'to turn away from a correct state, course or aim'. If your intervention has done nothing to alter something's course, then (by the $O E D$ 's light) what you have done cannot be said to have perverted it.

That is not the way the legal offence of 'perverting the course of justice' works, however. You are guilty of 'perverting the course of justice' whenever you have offered a judge a bribe, whether or not your bribe is accepted and whether or not it makes any difference to the judge's ruling. You are guilty of 'perverting the course of justice' whenever you destroy evidence, even if that evidence turns out to be superfluous to what is required to convict you. You are guilty of 'perverting the course of justice' whenever you make threats to jurors, even if someone else made even more scary threats that utterly eclipsed your own.

'Perverting the course of justice', as the common law construes it, is an 'attempt' concept rather than one that depends for its proper application on the success of the attempt. Certainly, you must have intended to alter the course of justice when you acted, in order to be properly charged with that offence; but you do not have to have succeeded in order to have committed the offence in question. There is nothing odd or unfamiliar about the thought that, if it is wrong to do something, it is wrong to attempt to do it. If it is wrong to insult your host or poison his dog, it is wrong - and wrong for much the same reason - to attempt to insult your host or poison his dog.

We think this way in criminal contexts all the time. In England, the Criminal Attempts Act makes attempting to commit a crime itself a crime. ${ }^{16}$ You remain liable to prosecution for that lesser crime, even if you fail in your attempt at committing the greater crime.

Something similar is true with 'perverting the course of justice', although a peculiarity of the common-law construction of the offence might obscure that fact slightly. In criminal law, 'murder' and 'attempted murder' are separate offences, as are 'assault' and 'aggravated assault'. In the common law offence of 'perverting the course of justice', in contrast, both failed attempts and successful performances are bundled together into the same offence. ${ }^{17}$

However, just because there is no separate offence carrying the name 'attempting to pervert the course of justice', we ought not to be misled into supposing that unsuccessful attempts are immune from prosecution. Quite the contrary: as the Crown Prosecution Service emphasizes, 'It does not matter whether or not the acts result in a[n actual] perversion of the course of justice: the offence is committed when the acts tending and intended to pervert a course of justice are done. ${ }^{18}$

${ }^{16}$ In Britain, for example, under the Criminal Attempts Act of 1981.

17 The British Crown Prosecution Service thus reminds prosecutors that the offence of 'perverting the course of justice' is to be 'charged contrary to common law, not the Criminal Attempts Act of 1981'. Different charging standards and different penalties attach to successful versus unsuccessful attempts at perverting the course of justice, and to acts causing serious versus trivial harm; see the Crown Prosecution Service's advice on 'charging practice'. But all are instances of the same offence. See the Crown Prosecution Service, 'Public Justice Offences Incorporating Charging Standard' (2007), available at: 〈cps.gov.uk/legal/section22/chapter_a.html〉 (accessed 14 June 2007).

${ }_{18}$ The Crown Prosecution Service, 'Public Justice Offences Incorporating Charging Standard', thus advises that although the offence 'is sometimes referred to as "attempting to pervert the course of justice", the words "attempting to" should not appear in the charge'. 
The same seems true too in the case of 'perverting the course of politics', through corruption, intimidation or lying. Suppose you have told some big lies about some matter of central concern on the floor of Parliament. But suppose your lies made no difference to the outcome: suppose that no one believed your lies; or suppose that no one did anything differently on the basis of their believing your lies; or suppose that someone else told even bigger lies that cancelled out your own. The fact that your lies made no difference to the parliamentary outcome does not erase the fact that you have 'lied to Parliament', which has long been considered one of the most heinous offences against Westminster institutions. ${ }^{19}$ And we should say the same about failed attempts at bribery or intimidation: the laws that make it illegal to attempt to alter the course of an election by bribing or intimidating voters do not exonerate the perpetrator whenever his attempt is unsuccessful and the other side still wins the election, despite his best efforts at bribery or intimidation.

So the fact that what I did 'made no difference' (because 'someone else would have, if I hadn't', or whatever) does not excuse acts 'perverting the course of politics'. As with justice, so too with politics: the 'perversion' comes in attempting to influence it through perverse means, inappropriate to that sphere of human activity. Acts of bribery, lying or intimidation are procedurally wrong in both spheres, even where in any particular instance they fail to lead to any consequential wrongs.

For an analysis of why that should be so, we need simply to reflect upon the fact that at the core of the wrong in both cases is 'bad intent'. While people can be guilty of 'perverting the course of justice' without succeeding in changing the outcome of some legal proceeding, they cannot be guilty of that offence unless they acted as they did with the intention of changing the outcome. ${ }^{20}$ As the British Crown Prosecution Service advises, people ought to be charged with 'perverting the course of justice' only if their action was: 'deliberate and elaborately planned' rather than 'spontaneous and unplanned'; 'prolonged and determined' as opposed to 'momentary and irresolute'; 'part of a concerted effort to avoid, pervert or defeat justice' rather than, for example, being 'motivated by misplaced loyalty to a relative [or] friend'. ${ }^{21}$

Politics may differ in those respects. Spontaneous, unplanned action may be less common there than in ordinary personal affairs. Of course, political actors do act 'in the heat of the moment' sometimes, too; but deliberately trying to alter the course of politics altering the political outcomes - is something people engaging in political action do all the time. It is perfectly proper that they should do so. That is what politics is all about.

Moreover, as in legal proceedings, so too in political proceedings: there are right and wrong ways to try to alter outcomes. Anyone deliberately attempting to alter the outcome of either by illicit means - bribery, lying or intimidation - is guilty of intending to "pervert

19 May's general characterization of 'contempts of Parliament' - of which 'making a deliberately misleading statement to Parliament' is one - is as 'any act or omission which obstructs of impedes either House of Parliament in the performance of its function, ... or which has a tendency, directly or indirectly, to produce such results'. The last phrase ('has a tendency ... to produce such results') is designed to include cases like failed attempts. See Erskine May, The Law, Privileges, Proceedings and Usage of Parliament, ed. C. J. Boulton, 25th edn (London: Butterworth, 1989), p. 115.

${ }^{20}$ More specifically, 'The offence of perverting the course of justice is committed when an accused does an act or series of acts, which has or have a tendency to pervert; and which is or are intended to pervert the course of justice'. Acts performed with the intention of perverting the course of justice, but which do not actually have a tendency to do so (like casting a magic spell on a non-believing judge), would thus not count. See the Crown Prosecution Service, 'Public Justice Offences Incorporating Charging Standard', quoting John Frederick Archbold, Pleading, Evidence and Practice in Criminal Cases (London: Sweet \& Maxwell, 1996), paras 28:1 to 28:28.

21 The Crown Prosecution Service, 'Public Justice Offences Incorporating Charging Standard'. 
the course of politics' just as surely as a counterpart in legal proceedings would be guilty of intending to 'pervert the course of justice'.

It is the evil intention rather than the actual outcome that constitutes the core of perverting the course of justice - or of politics either. People who have acted with the intention of altering outcomes in illicit ways are guilty of that sort of wrong, even if in the end what they did 'made no difference' to the actual outcome. We see that clearly in the administration of justice. Criminal attempts are crimes, whether or not they succeed. Failed attempts at wrong-doing are not all right, merely because they have failed.

Analysing what it is to 'pervert the course of politics' as analogous to 'perverting the course of justice' helps us see that the same clearly ought to be true in politics as in the administration of justice. Unsuccessful attempts at perverting the course of politics do not cease to be wrong merely by being unsuccessful. The wrong lies in the evil intention involved in deliberately adopting proscribed procedures in order to alter political outcomes in illicit ways.

Hence, the fact that what a political actor has done in the end 'made no difference' to the outcome is no excuse. The wrong does not depend on successful performance. It depends merely on intentional adoption of proscribed procedures designed to alter political outcomes, whether or not the attempt succeeds.

\section{They Could and Should Have Resisted}

Another way of attempting to excuse lying, bribery and intimidation in politics involves, in effect, 'blaming the victim'. Here, the claim is that these practices are all right, because 'those who succumbed to them could always have resisted'.

People with political power and authority - ranging from rulers through public servants to ordinary voters - presumably always have a duty to decide issues on the basis of the right reasons, and to resist temptations to decide them on the basis of wrong reasons. Set 'the right reasons' to one side: those may well vary, depending on particulars of the political system. 'Wrong reasons', however, are less variable. In any polity aspiring to be 'ruled via rules' (and for reasons I have discussed, that is most polities), 'wrong reasons' will invariably include the perversions I have been discussing: force and fraud and bribery.

Suppose, then, that we are discussing one of the typical polities where people with political power and authority - rulers, public servants, voters - do indeed have a duty to resist those perverse sorts of influences in making political decisions. Suppose that they fail to resist those influences, when they could and should have done so. Then we would indeed hold them responsible for their failure.

Of course, a threat or offer or untruth might sometimes be literally 'irresistible'. We might - or might not - be inclined to excuse people's failure to resist in those cases. ${ }^{22}$ Nevertheless, even if it would always have been wrong for Spiro Agnew to have accepted a bribe, his fault seems to have been compounded by the fact that he succumbed to such a low bribe. He really should have been able to resist that paltry sum of money.

Most of the bribes, lies and intimidation practised politically seem to be of that eminently resistible sort. Anyway, that is the thought being urged by the excuse now under discussion. It denies that those practices ought to be seen as 'perverting the course of politics', not

22 The 'dirty hands' thought suggests that we might want to say that people in positions of political power and authority do something wrong - have dirty hands - even when they could not have done otherwise. See Michael Walzer, 'Political Action: The Problem of Dirty Hands', Philosophy \& Public Affairs, 2 (1973), 160-80. 
because they have not changed the course of politics (as the previous excuse claimed), but rather because they need not have done so. People subject to those practices could and should have been able to resist them. They could and should have refused the bribes, exposed the lies, refused to be intimidated; and had they done as they could and should have done, the perverse practices would have made no difference to the outcomes.

I have already argued, of course, that the crucial thing is not whether an intervention has altered the outcome. Failed attempts at altering the outcome wrongly are wrong, and for much the same reason, as are successful ones. So the second excuse fails at exactly the same point as the first.

The 'they could have resisted' excuse fails for a further reason as well, however. Maybe the targets of attempted bribery, lying and intimidation fail in their duties by succumbing, when they could and should have resisted. Maybe the victims of those practices do deserve blame, too. But that does nothing to excuse the perpetrators of those practices. The fact that I should not have accepted your bribe does not make it all right for you to have offered it. The fact that I should not have believed your lie does not make it all right for you to have told the lie. The fact that I should have shrugged off your threats does not make it all right for you to have threatened me. It is perfectly possible for both the victim and the perpetrator to be in the wrong, as both clearly seem to be in these sorts of cases.

Once again, that is brought out clearly by looking at the judicial analogue, 'perverting the course of justice'. Judges and jurors and police all have a strict legal duty not to allow themselves to be influenced in the course of their official duties by offers of bribes. Although it is clearly wrong for them to take bribes, the fact that they do in no way mitigates the wrong done by someone offering them the bribe.

The wrongs of the briber and the bribed are thus separable wrongs. The briber is guilty of 'perverting the course of justice' whenever offering a bribe. Just as the briber is no less guilty of that offence if those being offered the bribe refuse it (as I have argued earlier), so too is the briber no less guilty of 'perverting the course of justice' if they accept it.

'Perverting the course of politics' ought to be seen as strictly analogous to 'perverting the course of justice' in those respects. Political actors ought not to allow themselves to be influenced in the course of their official duties by bribery, lies or intimidation, either. Were they to resist those influences, the attempts at bribery, lying and intimidation would fail and they would end up making no difference to the ultimate political outcome. Yet in the political, just as in the legal, case, that would in no way mitigate the wrong committed by someone in attempting to bribe them, to lie to them or to intimidate them. Nor is the wrongfulness of bribing, lying to or intimidating people politically mitigated if others succumb to the bribes, lies or intimidation.

\section{All's Fair in Love, War and Politics}

A third excuse, related to the other two, would be that bribery, intimidation and lying are 'just part of the game' in politics. Everyone does it. Everyone expects, or should expect, everyone else to do it. Everyone should be prepared to take countermeasures against everyone else's doing it. No one who properly understands the nature of the political game could ever think otherwise - or so a particularly hard-bitten 'realist' might insist.

It is true enough that if we voluntarily consent to play a game with known rules, then we cannot complain when other players act in accordance with those rules. When a boxer gets hit in the course of a match conducted strictly in accordance with the well-known Queensbury rules, he can hardly cry foul. His opponent has done nothing to wrong him. 
In applying this proposition to politics, we need first to ask, 'What exactly are the rules of the political game?' Are bribery, intimidation and lying really included among the practices that are generally accepted or understood as being permissible there? Not according to the statute books. There are laws against bribing public officials. There are laws against threatening people. Lying to Parliament is (or anyway until recently was) contrary to the strongest norm of Westminster systems.

To the hard-bitten realist, such formal rules count for little, and general practice is everything. Only a fool would take formal rules seriously, when actual practice is systematically otherwise. Yet the very fact that realists seem to think that they are telling people something they do not already know is in itself evidence that it is not generally known that formal legal expectations are fictitious; and if the 'rules of the game' argument crucially depends on what 'people know or ought to be expected to know', the fact that the realist message is supposed to be news is in itself powerful evidence that the excuse in view simply does not apply.

The 'rules of the game' excuse ultimately rests on a suppressed principle of fair competition. Politics is a competitive struggle for votes, for power, for control over social outcomes. It is fair that you can do to the other side the same as they can do to you. A sort of 'competitive licence' arises out of the fundamental symmetry in such situations. It would be unfair to expect you to abide by rules that others do not.

Competitors in a game are licensed to behave in certain ways by the rules of the game. They are licensed to behave in that way by the facts that other players of the game will behave in those ways, and that behaving in that way is the best (perhaps only) way they can counteract others behaving in that way. That is the sort of thing that is quite commonly heard in political connections. The fact that the other side bribes and intimidates people justifies our side in doing so. The fact that the other side lies justifies our side in doing the same. Fair's fair.

To call that political cynicism into question, we merely need to consider the judicial analogue. The judicial process is a competition, too: between opposing counsel, representing opposing interests. In courts, the fact that opposing counsel has fabricated evidence does not justify you in fabricating evidence. If both of you fabricate evidence, you both are guilty of the offence of 'perverting the course of justice'.

The excuse under discussion purports to give each adversary a 'competitive licence' to counteract what the other side has done by doing the same thing itself. If that were so, then there would be no objection to your offering 'merely to match the other side's bribes, no more'. But in the courts, anyone doing that is still clearly guilty of 'perverting the course of justice'. The fact that they merely matched - and hence merely neutralize - the other side's wrongdoing does nothing to excuse their own wrongdoing.

So too, I submit, with 'perverting the course of politics'. In the same way, and for the same reasons, as we would refuse to excuse the lies of one counsel just because opposing counsel has lied in court, so too should we refuse to excuse the lies of one side of politics just because the other side has lied. Two wrongs simply do not make a right, even if they just have the effect of cancelling each other out.

\section{INTERIM CONCLUSION}

The main aim of this article has been to resist resigned realists' cynicism about politics, and to do so in broadly their own terms. Resigned realists would say, with a sigh, that the 
sorts of things I have been discussing - bribery, intimidation, lying - are the sort of things that happen all the time in politics. Force and the threat of force has been the currency of politics since time immemorial. Since long before spin-doctors and sexed-up dossiers, successful politicians have ruled through a cunning combination of deception and selective candour. Trading public policy for political support lies as much at the heart of today's democratic competition for people's votes as it did in the days of courtly intrigues. Prigs might call these perversions; but if perversions they be, they will always be with us or so the resigned realist would say, with a sigh.

So far, I have been attempting to meet the resigned realists on their own ground. Up to this point, I have assiduously avoided any priggish appeal to high principle. I have eschewed any appeal even to fundamental democratic principles, in my indictment of those practices as 'perverting the course of politics'. Instead, I have up to this point cast my criticisms in terms of low pragmatism. Bribery, intimidation and lying are bad for rulers and bad for those being ruled. They are bad for both, simply because they interfere with 'ruling via rules', which works to the advantage of both.

Pragmatic expediency of that sort is a thin, low principle. ${ }^{23}$ Nonetheless, it spreads widely, to all sorts of regimes well beyond the high-mindedly democratic. It gives even the most unprincipled a reason that should resonate. Whatever else we might want to say against the perversions, the sheer pragmatics of efficient and effective political rule should set pretty much everyone against bribery, intimidation and lying.

In politics just as in the law, those practices get in the way of people anticipating the rules to which they will be held, and applying those rules to and for themselves. There are more, and doubtless more important, things wrong with the practices than that in each realm, but that minimal objection carries across both realms. And it does so in ways that enable us to see clearly just how disingenuous some of the standard political excuses for those practices actually are. In strictly analogous judicial settings, those excuses would be laughed out of court. I submit that we should do the same, and for the same reasons, in politics.

\section{RETURNING TO MORALLY HIGHER GROUND}

In closing, let me at least allude to some of the other more high-minded, principled reasons that we might have for endorsing the same conclusions. While these reasons would not move the political realist who constitutes the main target of this article, they are reasons that would rightly be dear to those who will constitute the natural constituency for this article. It is only fitting that, having stooped to join issue with resigned realists on their own home ground, I should return in closing to higher ground to remind myself why I should join issue with them at all.

I have already alluded to one set of more high-minded principles that would pit us against lying, bribery and intimidation. Those practices undermine democratic political equality. Instead of everyone counting for one, bribers, intimidators and liars in effect count for far more than one; in so far as they successfully control policy through their nefarious practices, they might even be said to 'exclude' all others from the political process. ${ }^{24}$ Democratic politics amounts to 'giving laws to ourselves'. Where bribery,

${ }^{23}$ Michael Walzer, Thick and Thin (Notre Dame, Ind.: University of Notre Dame Press, 1994).

${ }^{24}$ Mark Warren, 'What Does Corruption Mean in a Democracy?' American Journal of Political Science, 48 (2004), 328-43. 
intimidation or lying is politically common, laws are in effect given to us not by ourselves but rather by the miscreants engaging in those practices. In the same way that it is a matter of 'natural justice' that laws be applied in the ways involved in 'ruling via rules', it might be said to be a matter of 'democratic justice' that laws be made in the ways involved in 'ruling via rules'. For those seeking a more high-minded way of criticizing bribery, intimidation and lying in politics, there are plenty of avenues of that sort within democratic theory.

That is true and important, but an even more fundamental principle might be at stake. Not only do lying, bribery and intimidation interfere with collective democratic self-government. Those practices, when exercised either in the making or the application of coercively enforced laws, interfere even more importantly with individual selfgovernment. It is a fundamental element of one's 'autonomy' that one can make at least moderately efficacious plans and choices to lead one's life as one sees fit. Such planning and choosing can only be moderately efficacious, in turn, when it is being done against a moderately settled background of constraints and opportunities. That is what a system of settled law provides. It is an enabling condition of personal autonomy. It is most fundamentally why 'rule via rules' matters, morally.

That is just to say that there is some independent moral value to the 'rule of law', over and above the moral value of the specific rules of law that are being applied. That is not to say that the moral value of the specific rules does not matter, of course. It merely is to say that, whatever their value, there is some extra value to be had from making and applying them in an orderly manner following due processes. If substantive content of the specific rules of law is morally good, then that fact provides yet another reason for applying them systematically in this way. If the substantive content of the specific rules is morally bad, then that fact provides a reason against retaining or systematically applying them. If the specific rules are sufficiently bad, then that might outweigh altogether the 'rule-of-law' considerations-based reasons for retaining and systematically applying the existing rules.

All writers on the rule of law say as much, and it is important that they do so. Ruling via rules is, as Hart says, 'unfortunately compatible with very great iniquity'. ${ }^{25}$ Systematically applying the Rule of Law when the laws in question prescribe apartheid is no good thing; the less systematically those laws are applied and the sooner they are repealed, the better. ${ }^{26}$ The arguments just given for settled law as providing background conditions for the exercise of personal choice and autonomy do not constitute an ironclad argument, merely a defeasible presumption, against changing the law from time to time. The cost to autonomy of unsettling people's existing plans must simply be weighed against the gains that would come from shifting to a new set of arrangements that would enhance autonomy above that cost. ${ }^{27}$

25 Hart, Concept of Law, p. 207.

26 As Raz remarks: 'Since the rule of law is just one of the virtues law should possess, it is to be expected that it possesses no more than prima facie authority ... Conflict between the rule of law and other values is just what is to be expected ... [O]ther things being equal, the greater the conformity [to the rule of law] the better - [but] other things are rarely equal. A lesser degree of conformity is often to be preferred precisely because it helps realisation of other goals' ('The Rule of Law and Its Virtue', p. 210).

27 Purely in the spirit of mapping the logical space, I ought to acknowledge the possibility that by the same token occasionally the actions leading to the perversion I have been discussing here (lying, bribery and intimidation) might conceivably be autonomy enhancing, not just for those engaging in those practices but also for those subject to them. While logically possible, that would probably be very rare in practice, however. 
Thus, while there are low pragmatic reasons for even resigned realists to regard bribery, lying and intimidation as unacceptable 'perversions' both in making and applying the laws, there are other more high-minded reasons ultimately to do with autonomy and personal self-government to concur all the more strongly in that judgement. 'Ruling via rules' has special moral value in that connection. Its value is not absolute, trumping any potential moral 'disvalue' of the specific rules being imposed. But its value is not purely derivative from the moral value of those specific rules, either. 